Vladimir Pogačnik

UDK 811.133.1'373.611:003.083

Univerza v Ljubljani

Filozofska fakulteta

vladimir.pogacnik@ff.uni-lj.si
DOI: $10.4312 /$ vestnik.7.103-107

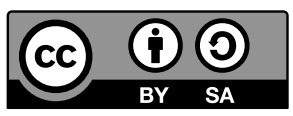

\title{
NOVEJŠE KRAJŠAVE V POGOVORNI FRANCOŠČINI
}

\section{UVOD}

Mineva natanko 40 let od zagovora mojega magistrskega dela z naslovom »Nekatere leksikalne in sintaktične posebnosti sodobnega francoskega ljudskega jezika v zvezi s krajšavami«, ki sem ga opravil pred komisijo, ki jo je vodil mentor prof. dr. Anton Grad.

Ko mi je pred kratkim prišla $\mathrm{v}$ roke, sem spet začutil svojo nekdanjo jezikoslovno vznemirjenost ob najrazličnejših pojavih brahiologije, ki se je bila tako razmahnila v nenormirani francoščini že vsaj v začetku stoletja in na kar je opozorila že slovita Grammaire des fautes (1929), ki jo je v postsaussurjanskem času v Ženevi objavil Henri Frei.

Eno od pomembnih središč, ki je znatno prispevalo k širitvi tega morfološkega pojava je argojska jezikovna inačica francoskih vojakov v I. svetovni vojski, imenovanih »poilus« (možatih, t.j. »kosmatih«). V novejšem času so se temu morfološkemu pojavu v neformalnem pisnem jeziku pridružili še drugi postopki, kot npr. kratice ali jezik SMS sporočil. Omenjeni postopki so zavzeli jezikovni prostor malodane vseh nam dostopnih jezikov, pri čemer slovenščina še zdaleč ne zaostaja.

Korpus, na katerem temelji članek, izhaja iz osebne izkušnje. Kot zvesti gledalec oddaje francoske televizije »Télématin« na frankofonski TV5, si kdaj pa kdaj zabeležim kakšne več ali manj nove »cvetke « - najbolj je zanje zaslužen komentator Patrice Romedenne, zadolžen za rubriko »pregled tiska«.

Vedoč, da je oddaji zvesta tudi naša draga jubilantka, prof. Elza Jereb, s katero sva 1971 oživila to za krajši čas zaspalo revijo, si kot nekakšno prijateljsko kozerijo (causerie!) drznem oblikovati manjši pregled nekaterih propulzivnih novejših krajšav, katerih repertoar bo morda zanimal naše mlajše kolegice in kolege.

\section{STAREJŠE KRAJŠAVE}

Pregled krajšav začenjamo $\mathrm{s}$ »srednje starimi« krajšavam, med katere lahko uvrstimo že splošno znane, od katerih se cela serija končuje na izglasje -o: ado, afro, alcoolo, folklo, intello, parano, ramollo (ramolli), homo, maso, sado, crado (cradingue, crasseux). 
Drugo:

Faf: [fasciste]:

Argojska inačica fafs (= dokumenti, papirji) je drugega izvora.

Dég: [dégoûté]:

Je suis dég. Gabi se mi, ne prenesem.

Dégueu: [dégueulasse]:

C'est vraiment dégueu. To je zares ogabno, nadvse umazano (tudi v moralnem smislu).

Zanimive so zlasti vzklične oblike:

A plus! [A plus tard],

A toute! [A toute à l'heure $]$

Bon ap! [Bon appétit]

Comme d'hab [Comme d'habitude].

\section{NOVEJŠE KRAJŠAVE}

L'actu: danes vsesplošno rabljena kratica za actualité [(naj)novejše dogajanje].

Perso: [personnel, personnellement]

C'est un travail un peu perso.

Zanimiva je v prvi vrsti adverbialna raba: Il joue trop perso [preveč solira - za igralca ekipnih iger].

Pro: [professionnel] nastopa kot samostalnik (un travail de pro) ali pridevnik (il est très pro). Verjetno je beseda po izvoru anglicizem, saj slovar Robert-Collins za angleščino navaja celo pro-am (professionnel amateur).

assoce: [association]:

J'ai découvert une assoce...(TV5).

allocs: [allocations familiales]

J'ai trouvé une alloc (TV5).

cata: [catastrophe]:

Pogosto rabljena krajšava zlasti v vzkličnih povedih: Oh, la cata!, Quelle cata, alors! conso: [consommation]:

Zdaj največ v splošnem pomenu potrošnja in ne več kot zapitek (konzumacija). conf: [conférence]:

Najstarejša rabljena okrajšava je verjetno specializirana sintagma: maître de conf (predavatelj,-ica).

Latino: [d'Amérique Latine]:

Samostalnik, m. in ž., pridevnik: L'ambiance latino du pays (TV5). Oh, les Latinos! Nedvomno gre za izposojenko iz ameriške angleščine z značilno špansko pripono - $O$, ki se je zaradi homofonije s francoskim -o dobro prijela tudi v francoščini.

Provoc: $[($ de) provocation, provocateur,-trice]: 
Les gens aiment bien cette touche un peu provoc. (TV5).

Médoc: [médicament]:

J'en ai marre de mes médocs. (TV5).

Texto: [textuellement; sous forme de texte]:

Voilà, je te dis texto.

Danes splošno rabljena beseda za SMS je bila sprva krajšava za prislov textuellement (= mot à mot, dobesedno).

J'ai envoyé un texto à mon frère.

Accro: [accroché]:

Krajšava ima dva pomena:

- être accro à la drogue = odvisnik, odvisen;

- les accros de deltaplane = strastni, fanatični privrženci zmajarstva.

Réac: [réactionnaire]:

Ustaljena je zlasti pridevniška raba: Il est vraiment réac (Zares je konzervativen). Uveljavlja se tudi samostalniška raba, izpeljana iz réaction: la réac médiatique (TV5).

V modi so tudi krajšave lastnih imen: Sarko, Schumi (Schumacher), Nat (Nathalie Ruwet-vremenarka na TV5) etc.

Dodamo naj še, da je kar nekaj starejših krajšav pridobilo nove pomene:

amphi: [amphithéâtre]:

Poleg pomena »(velika) predavalnica« se je pomen metonimično razširil tudi na »univerzitetno predavanje«: suivre un amphi.

labo: [laboratoire]:

Lahko pomeni »laboratorij« ali širše »raziskovalni inštitut«: Il travaille au labo (n.pr. Institut de la langue française).

prépa: [(de) préparation]:

Poleg nadomeščanja termina classe préparatoire (po maturi, kot priprava na »visoko šolo«) kratica označuje tudi pripravo nasploh: Le tournage du film a duré six mois avec la prépa (TV5).

Če je od starejših krajšav manif [manifestation] splošno rabljena, pa n.pr. manip [manipulation] redkeje srečujemo, dasi ji daje n.pr. Petit Robert kar letnico prve pojavitve 1880; enako velja za bourge [bourgeois].

Trdožive so seveda številne krajšave kot prof, télé, sécu, pub, maths, mat (à sept heures du mat), resto, R.U. in celo ru (restaurant universitaire) in še nešteto drugih, med njimi besedje iz športa, vzeto iz angleščine: foot, basket, hand itn.

Zadnji primeri odpirajo širše vprašanje vpliva angleščine na tvorbo krajšanih besed ali takih, ki dajejo vtis krajšave.

Čisto angleški so primeri kot gang [bande de malfaiteurs], buzz [le murmure, bourdonnement, coup de fil in v zadnjem času zlasti »govorice«: le buzz dit que Sarko va épouser Bruni], coach (chef de l'équipe), le show-biz (show-business), Net (Internet), ex (ex-mari, ex-femme). 
Tudi krajšavi iz tvorjenk détoxe [désintoxication; il fait une détoxe $=$ cure de détoxication] in intoxe [intoxication; C'est de l'intoxe $=c^{\prime}$ est de la pure propagande, du $» b r a i n-$ -washing «].

Bolj angleško zvenijo seveda cool, break [faire un break avec le travail] itn., ki spričo svoje kratkosti v francoskih ušesih zvenijo kot krajšave.

Na koncu omenimo še nekaj primerov, ki se nam zdijo več kot ekskluzivni: créa za créatif, giga za gigantesque, résulte za résultat, réu za réunion, reco za recommandation, fab za fabrication, négo za négociation, en exclu za en exclusivité. Na TV5 je bilo slišati tudi le Numa, ki je sestavljanka iz krajšav besed numérique in humain in ki je lastno ime za poslovne prostore v Parizu, kjer svoj sedež lahko najdejo mlada t. i. »start-up« podjetja.

\section{ZAKLJUČEK}

V članku smo želeli pokazati živost in odprtost besedotvornega postopka krajšav, ki zadeva večinoma samostalnike in pridevnike, pa tudi stalne besedne zveze, in ne izbira med izvirnimi francoskimi besedami in tujkami. Produktivnost temelji na dveh ključnih jezikovnih potrebah: potrebi po gospodarnosti in potrebi po bogati izraznosti, ki je lastna zlasti pogovornemu jeziku.

\section{BIBLIOGRAFIJA}

MANDELBAUM-REINER, Françoise (1991) Suffixation gratuite et signalétique textuelle d'argot. Langue française 90, 106-112.

VERDELHAN-BOURGADE, Michèle (1991) Procédés sémantiques et lexicaux en français branché. Langue française 90, 65-79.

POGAČNIK, Vladimir (1975) Nekatere leksikalne in sintaktične posebnosti sodobnega francoskega ljudskega jezika v zvezi s krajšavami. Ljubljana: FF UL (magistrsko delo).

\section{POVZETEK}

\section{Novejše krajšave v pogovorni francoščini}

Avtor se v članku vrača $\mathrm{k}$ besedotvornemu postopku krajšav, ki ga je raziskoval že pred štiridesetimi leti v svojem magistrskem delu. Članek želi na primeru korpusa, ki je nastal na podlagi spremljanja oddaje Télématin na frankofonski televizijski mreži TV5, dokazati, da je krajšanje živ in razširjen postopek, ki se pojavlja predvsem v različnih oblikah govorne komunikacije.

Ključne besede: francoščina, pogovorni jezik, besedotvorje, krajšave 


\section{ABSTRACT}

\section{New Abbreviations in Colloquial French}

The author of the article treats the process of abbreviations, which he explored forty years ago in his master thesis. The article is based on the corpus created on the basis of Télématin broadcast on French television network TV5. According to the author, clipping is a widespread process that occurs primarily in various forms of oral communication.

Key words: French, colloquial language, word formation, abbreviations 